\title{
Study on a calibration equation for soil water content in field tests using time domain reflectometry*
}

\author{
Yun ZHAO ${ }^{1,2}$, Dao-sheng LING ${ }^{\dagger 1,2}$, Yun-long WANG ${ }^{1,2}$, Bo HUANG ${ }^{1,2}$, Han-lin WANG ${ }^{1,2}$ \\ $\left({ }^{1}\right.$ MOE Key Laboratory of Soft Soils and Geoenvironmental Engineering, Zhejiang University, Hangzhou 310027, China) \\ ( ${ }^{2}$ Institute of Geotechnical Engineering, Zhejiang University, Hangzhou 310058, China) \\ †E-mail: dsling@zju.edu.cn
}

Received Mar. 24, 2015; Revision accepted July 8, 2015; Crosschecked Feb. 29, 2016

\begin{abstract}
The crucial point in calibrating soil water content using the technology of time domain reflectometry (TDR) is to establish the relationship between the apparent dielectric constant and the water content. Based on a database, which included 45 kinds of soil samples and 418 data points from our own test data and relevant literature, an empirical calibration equation is proposed. Additionally, the influence of soil type, dry density of soil, compaction energy, pore fluid conductivity, and temperature on the calculated result for water content was also analyzed. Results show that the equation can offer an error of $\pm 0.05 \mathrm{~g} / \mathrm{g}$ for most soils encountered in geotechnical engineering. However, the estimation error given by the empirical equation becomes significant for soils with dry density less than $1.3 \mathrm{~g} / \mathrm{cm}^{3}$, so the equation was modified to consider the influence of dry density. Both of the empirical equations can be used to test gravimetric water content using the TDR method conveniently and efficiently without calibration.
\end{abstract}

Key words: Soil, Gravimetric water content, Time domain reflectometry (TDR), Empirical calibration equation http://dx.doi.org/10.1631/jzus.A1500065

CLC number: TU413

\section{Introduction}

Water content is a basic parameter of the threephase-system of soil and affects soil behavior notably in geotechnical engineering. Obviously, therefore, it is of great significance to be able to test the water content of soil efficiently. The time domain reflectometry (TDR) method has been widely used to measure water content in agriculture, hydraulic engineering, geotechnical engineering, etc., for its advantages of speed, reliability, and the possibility of automatic monitoring (Drnevich et al., 2001; Noborio, 2001; Imhoff et al., 2007; Cui et al., 2013; Chen, 2014).

\footnotetext{
${ }^{\ddagger}$ Corresponding author

* Project supported by the National Basic Research Program (973 Program) of China (No. 2014CB047005)

(ib) ORCID: Yun ZHAO, http://orcid.org/0000-0002-7247-9968; Daosheng LING, http://orcid.org/0000-0002-0604-1175

(C) Zhejiang University and Springer-Verlag Berlin Heidelberg 2016
}

The crucial point in calibrating soil water content using TDR technology is to establish the relationship between the dielectric constant and the water content, which is usually referred to as the calibration equation. At present there are mainly two approaches to set up the equation. One is the volumetric mixing model, which acquires the dielectric constant of a mixture by taking a weighted average of the dielectric constant of each component in the mixture according to their volumetric proportions. Since this theoretical model is usually based on some assumptions, it has limitations in practical use (Birchak et al., 1974; Dobson et al., 1985; Heimovaara et al., 1994; Chen et al., 2003). The other approach is to find a purely empirical equation to fit the experimental data points. Among these empirical equations, Topp's equation is widely used (Topp et al., 1980). This equation shows that the relationship between apparent dielectric constant and volumetric water content is not sensitive to soil 
texture, soil bulk density, temperature, salt content, etc. Many studies found that this empirical equation had a high accuracy for inorganic soils but was inapplicable to organic soils, fine textural soils, and clay soils (Herkelrath et al., 1991; Jacobsen and Schjønning, 1993; Dirksen and Dasberg, 1993; Ponizovsky et al., 1999). There are also other types of empirical equations including a linear relationship between volumetric water content and the square root of the apparent dielectric constant (Hook and Livingston, 1996; Yu et al., 1997; Masbruch and Ferré, 2003). There are also equations considering the effect of soil density (Ledieu et al., 1986; Malicki et al., 1996). However, in geotechnical engineering, gravimetric water content is used more extensively. According to the theory of TDR, two physical quantities, dielectric constant and bulk electrical conductivity, of soil can be obtained through the TDR waveforms. The two parameters are used in an empirical relationship relating gravimetric water content and dry density. Siddiqui and Drnevich (1995) proposed a linear calibration equation to relate dielectric constant with gravimetric water content and dry density. Then the corresponding 'two-step method' was performed to obtain gravimetric water content and dry density from field measurements. $\mathrm{Yu}$ and Drnevich (2004) established a linear empirical calibration equation to relate bulk electrical conductivity to gravimetric water content and dry density. Using this equation with Siddiqui and Drnevich (1995)'s equation, only one TDR test is required to obtain the parameters of soil in situ. This method is called the 'one-step method'. Since the relationship between soil bulk electrical conductivity and gravimetric water content is not linear (Abu-Hassanein et al., 1996; Zambrano, 2006), Jung (2011) proposed a 'voltage normalization method' and developed a calibration equation between the voltage drop parameter and the apparent dielectric constant to replace the bulk electrical conductivity equation in the 'one-step method'. It is important that laboratory tests should be conducted to obtain the constants in the equations before using the 'one-step method' and the 'two-step method'.

Generally, after calibration of the constants of the empirical equations, water content can be measured in the laboratory and in the field by the TDR method conveniently and efficiently with a high accuracy. But for the reasons listed below, there are some constraints on applying these calibration equations in field tests:

1. The 'two-step method' takes time and energy to obtain the measurements for the field test. In particular, when continuous testing at different depths is required, this method will be invalid since it is difficult to perform the second TDR test.

2. For both the 'one-step method' and the 'twostep method', the constants of the calibration equations are soil-dependent. As the soil is usually heterogeneous in the field and not of a single soil type, the calibration of each soil's constants is difficult.

Hence, it is of great significance to propose a calibration equation that is applicable to various soils and correlates gravimetric water content with apparent dielectric constant directly in geotechnical practice. The object of this study is to establish such a calibration equation through analyzing TDR data points from laboratory tests and the literature.

\section{A new empirical calibration equation}

Herein, the soil-water-air three phase system of soil is described according to Hook and Livingston (1996) (Fig. 1). Solid particles are considered as an impervious layer with thickness $l_{\mathrm{s}}$ and dielectric constant $K_{\mathrm{s}}$ that can have adsorbed moisture. Liquid and air phases are also treated as a liquid layer and an air layer with thicknesses $l_{\mathrm{w}}$ and $l_{\mathrm{a}}$, and dielectric constants $K_{\mathrm{w}}$ and $K$, respectively. $X_{1}$ and $X_{2}$ represent the positions of the probe inserted into the soil. The relationship between the volumes of each phase is:

$$
l=l_{\mathrm{a}}+l_{\mathrm{w}}+l_{\mathrm{s}} .
$$

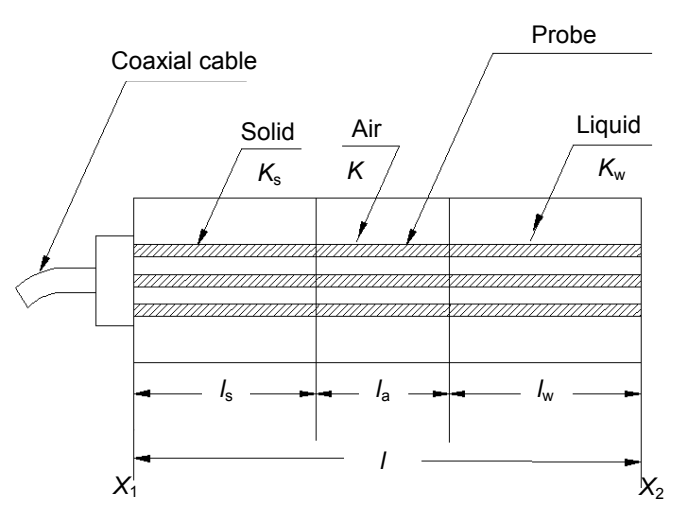

Fig. 1 Soil-water-air transmission line model (Reprinted from (Hook and Livingston, 1996), Copyright 1996, with permission from ACSESS) 
It is assumed that the total travel time of the TDR waveform through the tested soil sample is equal to the sum of the time in each phase, which can be given by

$$
t=t_{\mathrm{s}}+t_{\mathrm{w}}+t_{\mathrm{a}}
$$

where $t, t_{\mathrm{s}}, t_{\mathrm{w}}$, and $t_{\mathrm{a}}$ represent the time of TDR waveform travel in the system, solid particles, water, and air, respectively.

Topp et al. (1980) showed that the velocity of an electromagnetic wave travelling through the medium could be described by an apparent dielectric constant $K_{\mathrm{a}}$ :

$$
v=\frac{c}{\sqrt{K_{\mathrm{a}}}},
$$

where $v$ is the velocity of electromagnetic wave that travels through the medium, and $c$ is the velocity of an electromagnetic wave in free space (the apparent dielectric constant is also called the dielectric constant, so the two concepts are the same in this study).

The velocity of the TDR waveform in each phase can also be described by

$$
v_{i}=\frac{2 l_{i}}{t_{i}},
$$

where $i$ represents $\mathrm{s}, \mathrm{w}$, or a.

Combining Eqs. (2)-(4) leads to the equation:

$$
l \sqrt{K_{\mathrm{a}}}=l_{\mathrm{s}} \sqrt{K_{\mathrm{s}}}+l_{\mathrm{w}} \sqrt{K_{\mathrm{w}}}+l_{\mathrm{a}} \sqrt{K}
$$

Define $\alpha$ as the value of the volume of the air phase compared to the volume of the solid phase, i.e.,

$$
\alpha=\frac{l_{\mathrm{a}}}{l_{\mathrm{s}}},
$$

the gravimetric water content of soil can be expressed as

$$
w=\frac{l_{\mathrm{w}}}{G_{\mathrm{s}} l_{\mathrm{s}}},
$$

where $G_{\mathrm{s}}$ is the specific gravity of the solids.
Combining Eq. (1) and Eqs. (5)-(7) leads to Eq. (8):

$$
w=\frac{-\sqrt{K}-\frac{\sqrt{K_{\mathrm{s}}}-\sqrt{K}}{1+\alpha}+\sqrt{K_{\mathrm{a}}}}{G_{\mathrm{s}} \frac{\sqrt{K_{\mathrm{w}}}}{1+\alpha}-\frac{G_{\mathrm{s}}}{1+\alpha} \sqrt{K_{\mathrm{a}}}} .
$$

As shown in Eq. (8), the relationship between gravimetric water content and apparent dielectric constant is influenced by the dielectric constant of each component, the value of $\alpha$, etc. For most natural soils, the typical values of the dielectric constants of the solid phase $K_{\mathrm{s}}$, air phase $K$, and liquid phase $K_{\mathrm{w}}$ are $3-5,1$, and 81 , respectively. The value of the specific gravity of solids $G_{\mathrm{s}}$ is usually around 2.62.8. The parameters above can be regarded as constants. According to the definition of $\alpha, \alpha$ is less than the void ratio, which varies between 0.4-1.5 (Chen Y., 2011). Then, the range of $1 /(1+\alpha)$ is limited between 0.4-0.71, which represents the degree of compaction of the soil. Therefore, it assumes that treating $1 /(1+\alpha)$ as constant will introduce negligible errors for soils of different types and compaction. From Eq. (8), the calibration equation between gravimetric water content and apparent dielectric constant has the form of

$$
w=\frac{A+\sqrt{K_{\mathrm{a}}}}{B+C \sqrt{K_{\mathrm{a}}}},
$$

where $A, B$, and $C$ are empirical constants. Values of them are obtained through regression analysis of real tests.

\section{Data collection}

To obtain the parameters in Eq. (9) through regression analysis, a total of 418 data points from TDR tests of 45 soil samples from our experiments and from the literature were collected.

\subsection{Data from laboratory test}

Three types of soils commonly used in engineering were used to conduct the laboratory tests: Fujian sand, Qiantang silt, and one clay soil. The 
properties of these soils, including the specific gravity of solids $\left(G_{\mathrm{s}}\right)$, liquid limit $\left(L_{\mathrm{L}}\right)$, plasticity index $\left(P_{\mathrm{I}}\right)$, grain-size distributions, and the classified types by the Unified Soil Classification System (USCS) are shown in Table 1.

Table 1 Physical properties of soils in the laboratory tests

\begin{tabular}{lcccccccc}
\hline \multirow{2}{*}{ Soil } & \multirow{2}{*}{$\begin{array}{c}\text { USCS } \\
\text { type }\end{array}$} & \multirow{2}{*}{$G_{\mathrm{S}}$} & \multirow{2}{*}{$L_{\mathrm{L}}$} & \multirow{2}{*}{$P_{\mathrm{I}}$} & \multicolumn{3}{c}{ GSD (\%) } \\
\cline { 6 - 9 } & & & & Sand & Silt & Clay \\
\hline Fujian sand & $\mathrm{SP}$ & 2.64 & - & - & 100.0 & 0 & 0 \\
Qiantang silt & $\mathrm{ML}$ & 2.69 & 31.7 & 9.1 & 11.2 & 83.0 & 5.8 \\
Clay sand & $\mathrm{CL}$ & 2.66 & 48 & 15.4 & 11.4 & 51.9 & 36.7 \\
\hline
\end{tabular}

SP: poorly graded sand soils; ML: silt soils; CL: low plasticity clay soils; GSD: grain-size distribution

The TDR tests were conducted with the Campbell Scientific TDR 100 apparatus and its PCTDR software. The TDR waveforms are analyzed to obtain the dielectric constant (Baker and Allmaras, 1990). The probe used here is the same as the one recommended by ASTM (2012a) with a height of $116 \mathrm{~mm}$ for the compact mold.

Before the test, the soil samples were oven dried, pulverized, sieved first, and mixed with tap water to approach the targeted water contents. After being placed in a room with a constant temperature around $20{ }^{\circ} \mathrm{C}$ in a sealed plastic bag for $24 \mathrm{~h}$, the soil samples were then compacted in the mold according to ASTM (2012b) and a TDR test was performed. Finally the soil samples were oven dried to obtain the real gravimetric water content.

Through this method, the dielectric constant and the dry density of the sand, silt, and clay soil samples with seven, seven, and six different water contents, respectively, were obtained.

\subsection{Data from the field test}

Based on the pavement maintenance project of an airport in the west of China, TDR tests for soils of different depths at the pavement area and soil surface area were performed. Soil samples at targeted depths were taken by the dry drilling method. Part of the soil was sealed in plastic bags and tested by oven dry method while the rest was compacted in the mold for a TDR test. The properties of field soils are shown in Table 2.

As the test condition in the field was complex and time was limited, twelve data points were obtained.
Table 2 Physical properties of the field soils

\begin{tabular}{ccccccccc}
\hline \multirow{2}{*}{ Soil } & \multirow{2}{*}{$\begin{array}{c}\text { USCS } \\
\text { type }\end{array}$} & \multirow{2}{*}{$G_{\mathrm{s}}$} & \multirow{2}{*}{$L_{\mathrm{L}}$} & $P_{\mathrm{I}}$ & \multicolumn{3}{c}{ GSD (\%) } \\
\cline { 6 - 8 } & & & & Sand & Silt & Clay \\
\hline Airport-1 & $\mathrm{CL}$ & 2.61 & 47.3 & 33.4 & 7.1 & 74.0 & 18.9 \\
Airport-2 & $\mathrm{CL}$ & 2.64 & 35.9 & 11.8 & 15.6 & 65.2 & 19.2 \\
Airport-3 & $\mathrm{CL}$ & 2.75 & 35.1 & 14.9 & 23.8 & 60.7 & 15.5 \\
\hline
\end{tabular}

\subsection{Data from the literature}

Information from the literature on 39 soil samples and 386 TDR data points, including the values of dielectric constant, dry density, and gravimetric water content by the oven dry method, was used for re-analysis in this study. In this database, the number of samples for sandy soils, silt soils, and clay soils are 9,8 , and 22 , respectively. The range of gravimetric water content is $0-0.55 \mathrm{~g} / \mathrm{g}$ and dry density is $1.07-2.3 \mathrm{~g} / \mathrm{cm}^{3}$. Temperature varies from $4{ }^{\circ} \mathrm{C}$ to $40^{\circ} \mathrm{C}$. Properties of soils from the literature are shown in Table 3.

According to their properties, the soils collected are classified into four types: sandy soils (S), silt soils (ML), low plasticity clay soils (CL) and high plasticity clay soils $(\mathrm{CH})$. According to USCS, S soils include SW, SP, SM, SM-SC, and SM-SW soil types. CL soils include CL and CL-ML soil types. $\mathrm{CH}$ soils include $\mathrm{CH}$ and $\mathrm{CH}-\mathrm{CL}$ soil types. The compaction energy levels used in Jung (2011) on ASTM Reference Soils (ASTM, 2010) were 360, 600 , and $2700 \mathrm{~kJ} / \mathrm{m}^{3}$ for compaction methods of reduced compaction (RC), standard compaction (SC), and modified compaction (MC), respectively (ASTM, 2007; 2009). Lin (1999) used the same compaction methods to conduct a compaction test for M1-M5 soils. The values of electrical conductivity used by Jung (2011) to perform a TDR test on ASTM Reference Soils (ASTM, 2010) are about $62 \mathrm{mS} / \mathrm{m}$ for tap water and $130 \mathrm{mS} / \mathrm{m}$ for saline water.

\section{Results and discussion}

\subsection{Regression analysis}

The data base collected above was used to obtain the parameters in Eq. (9) through regression analysis. As shown in Fig. 2 (p.245), ten points labeled with squares show great disparity, and these 
Table 3 Properties of the soils from literatures

\begin{tabular}{|c|c|c|c|c|c|c|c|c|c|c|c|c|}
\hline \multirow{2}{*}{ Soil } & \multirow{2}{*}{$\begin{array}{l}\text { USCS } \\
\text { type }\end{array}$} & \multirow{2}{*}{$G_{\mathrm{s}}$} & \multirow{2}{*}{$L_{\mathrm{L}}$} & \multirow{2}{*}{$P_{\mathrm{I}}$} & \multicolumn{3}{|c|}{ GSD (\%) } & \multirow{2}{*}{$\begin{array}{c}\text { Compaction } \\
\text { method }\end{array}$} & \multirow{2}{*}{$\begin{array}{l}\text { Tempera- } \\
\text { ture }\left({ }^{\circ} \mathrm{C}\right)\end{array}$} & \multirow{2}{*}{$\begin{array}{l}\text { Pore } \\
\text { fluid }\end{array}$} & \multirow{2}{*}{ NDS } & \multirow{2}{*}{ Reference } \\
\hline & & & & & Sand & Silt & Clay & & & & & \\
\hline A1 & SW & - & - & - & - & - & - & $\mathrm{SC}$ & Room & $\mathrm{CaCl}_{2}$ & 6 & Chen et al. (2014) \\
\hline A2 & ML & - & - & - & - & - & - & $\mathrm{SC}$ & Room & $\mathrm{CaCl}_{2}$ & 7 & Chen et al. (2014) \\
\hline $\mathrm{A} 3$ & $\mathrm{CL}$ & - & - & - & - & - & - & $\mathrm{SC}$ & Room & $\mathrm{CaCl}_{2}$ & 7 & Chen et al. (2014) \\
\hline Silt & ML & 2.67 & - & - & 5.7 & 93.7 & 0.6 & $\mathrm{SC}$ & Room & TAP & 6 & $\mathrm{Xu}(2008)$ \\
\hline $\begin{array}{l}\text { Xiaoshan } \\
\text { clay }\end{array}$ & $\mathrm{CL}$ & 2.69 & 34 & 23 & 0 & 69.6 & 30.4 & $\mathrm{SC}$ & Room & TAP & 5 & $\mathrm{Xu}(2008)$ \\
\hline Bentonite & $\mathrm{CH}$ & 2.82 & 60 & 45 & 29.5 & 39.8 & 30.7 & $\mathrm{SC}$ & Room & TAP & 5 & $\mathrm{Xu}(2008)$ \\
\hline Crosby till & CL-ML & - & 41 & 23 & 16 & 50 & 34 & $\mathrm{SC}$ & $\begin{array}{c}4,10,20, \\
30,40\end{array}$ & TAP & 31 & Drnevich et al. (2001) \\
\hline Kaolinite & CL & - & 30 & 6 & 0 & 0 & 100 & $\mathrm{SC}$ & $4,20,30$ & TAP & 8 & Drnevich et al. (2001) \\
\hline Illite & $\mathrm{CH}-\mathrm{CL}$ & - & 50 & 28 & 0 & 0 & 100 & $\mathrm{SC}$ & $4,20,30$ & TAP & 7 & Drnevich et al. (2001) \\
\hline $\begin{array}{l}\text { Concrete } \\
\text { sand }\end{array}$ & SW & - & - & - & 100 & 0 & 0 & $\mathrm{SC}$ & $4,20,40$ & TAP & 6 & Drnevich et al. (2001) \\
\hline Fine sand & SP & 2.65 & - & - & 100 & 0 & 0 & $\mathrm{SC}$ & $4,20,40$ & TAP & 6 & Drnevich et al. (2001) \\
\hline $\begin{array}{l}\text { Houston } \\
\text { clay }\end{array}$ & $\mathrm{CH}$ & - & 54 & 31 & 0 & $5^{*}$ & $95^{*}$ & $\mathrm{SC}$ & $\begin{array}{c}4,10,20 \\
30,40\end{array}$ & TAP & 30 & Drnevich et al. (2001) \\
\hline Grade sand & SW & - & - & - & - & - & - & $\mathrm{SC}$ & Room & TAP & 4 & $\begin{array}{c}\text { Yu and Drnevich } \\
\text { (2004) }\end{array}$ \\
\hline Silt & ML & 2.69 & 32 & 9 & 11.2 & 83.0 & 5.8 & $\mathrm{SC}$ & Room & - & 5 & Chen W. (2011) \\
\hline Silt sand & SM & 2.66 & 28.1 & 5 & - & - & - & $\mathrm{SC}$ & Room & - & 6 & Chen W. (2011) \\
\hline Silt & ML & 2.68 & 28.9 & 6 & - & - & - & $\mathrm{SC}$ & Room & - & 5 & Chen W. (2011) \\
\hline Mucky soil & $\mathrm{CL}$ & 2.73 & 33.4 & 14.9 & - & - & - & $\mathrm{SC}$ & Room & - & 7 & Chen W. (2011) \\
\hline Silt clay & CL-ML & 2.72 & 30.3 & 13.4 & - & - & - & $\mathrm{SC}$ & Room & - & 7 & Chen W. (2011) \\
\hline Vigo & $\mathrm{CL}$ & - & 36 & 12 & - & - & - & $\mathrm{SC}, \mathrm{MC}$ & Room & - & 9 & Feng et al. (1998) \\
\hline Hendricks I & $\mathrm{CL}$ & - & 37 & 13 & - & - & - & $\mathrm{SC}, \mathrm{MC}$ & Room & - & 5 & Feng et al. (1998) \\
\hline Indianapolis & ML & - & 15 & - & - & - & - & $\mathrm{SC}, \mathrm{MC}$ & Room & - & 9 & Feng et al. (1998) \\
\hline Hendricks II & $\mathrm{CL}$ & - & 32 & 11 & - & - & - & $\mathrm{SC}, \mathrm{MC}$ & Room & - & 10 & Feng et al. (1998) \\
\hline $\begin{array}{l}\text { Blooming- } \\
\text { ton }\end{array}$ & CL-CH & - & 50 & 24 & - & - & - & $\mathrm{SC}, \mathrm{MC}$ & Room & - & 9 & Feng et al. (1998) \\
\hline ASTM-CH & $\mathrm{CH}$ & 2.72 & 59.8 & 39.2 & 1.2 & 42.5 & 56.3 & $\mathrm{SC}, \mathrm{MC}, \mathrm{RC}$ & 20 & $\begin{array}{c}\text { TAP, } \\
\text { DI, } \\
\text { SAL }\end{array}$ & 29 & Jung (2011) \\
\hline ASTM-CL & $\mathrm{CL}$ & 2.67 & 33.4 & 13.6 & 11.5 & 42.5 & 46 & $\mathrm{SC}, \mathrm{MC}, \mathrm{RC}$ & 20 & TAP & 15 & Jung (2011) \\
\hline ASTM-ML & ML & 2.73 & 27.4 & 4.1 & 1 & 94 & 5 & $\mathrm{SC}, \mathrm{MC}, \mathrm{RC}$ & 20 & TAP & 15 & Jung (2011) \\
\hline ASTM-SP & SP & 2.66 & - & - & 99 & - & - & $\mathrm{SC}, \mathrm{MC}, \mathrm{RC}$ & 20 & TAP & 19 & Jung (2011) \\
\hline M1 & SM-SC & 2.76 & - & - & 55 & 35 & 10 & $\mathrm{SC}, \mathrm{MC}, \mathrm{RC}$ & 20 & TAP & 12 & Jung (2011) \\
\hline M2 & ML & 2.77 & 16.2 & 5.7 & 37.5 & 45.0 & 17.5 & $\mathrm{SC}, \mathrm{MC}, \mathrm{RC}$ & 20 & TAP & 14 & Jung (2011) \\
\hline M3 & $\mathrm{CL}$ & 2.83 & 28.5 & 16.2 & 20 & 55 & 25 & $\mathrm{SC}, \mathrm{MC}, \mathrm{RC}$ & 20 & TAP & 12 & Jung (2011) \\
\hline M4 & CL & 2.83 & 33.7 & 14.8 & 12.5 & 47.5 & 40 & $\mathrm{SC}, \mathrm{MC}, \mathrm{RC}$ & 20 & TAP & 13 & Jung (2011) \\
\hline M5 & $\mathrm{CL}$ & 2.82 & 41 & 21.1 & 5 & 40 & 55 & $\mathrm{SC}, \mathrm{MC}, \mathrm{RC}$ & 20 & TAP & 13 & Jung (2011) \\
\hline GRP & $\mathrm{CL}$ & 2.68 & 31.1 & 15.8 & 12 & 60.5 & 27.5 & - & $21-23$ & - & 6 & Jung (2011) \\
\hline SAG & SM-SW & 2.72 & - & - & 65.3 & 16.4 & 9 & - & $21-23$ & - & 5 & Jung (2011) \\
\hline DFA & CL-ML & 2.62 & 17.6 & 5.3 & 35 & 50.4 & 14.6 & - & $21-23$ & - & 5 & Jung (2011) \\
\hline Poor sand & SP & - & - & - & 98.7 & 1.34 & - & $\mathrm{SC}, \mathrm{MC}$ & - & - & 11 & Rathje et al. (2006) \\
\hline Taylor clay & $\mathrm{CH}$ & - & - & - & 4.17 & 95.8 & - & $\mathrm{SC}$ & - & - & 5 & Rathje et al. (2006) \\
\hline Clay & $\mathrm{CL}$ & - & - & - & 12.2 & 77.9 & - & $\mathrm{SC}$ & - & - & 6 & Rathje et al. (2006) \\
\hline Sandy clay & $\mathrm{CH}$ & - & - & - & 37.2 & 62.9 & - & $\mathrm{SC}$ & - & - & 6 & Rathje et al. (2006) \\
\hline
\end{tabular}

SW: well-graded sand soils; SM: silt sand soils; NDS: number of data samples; TAP: tap water; DI: deionized water; SAL: saline water (about twice pore fluid conductivity of TAP); ${ }^{*}$ : the data is estimated; Room: room temperature, usually around $20^{\circ} \mathrm{C}$ 
points were omitted during data fitting. At the same time, only the data points at $20{ }^{\circ} \mathrm{C}$ given by Drnevich et al. (2001) were adopted for the regression analysis. It should be pointed out that the subsequent statistical analysis covered the ten omitted scattered points. The results of regression analysis are shown in Fig. 2 and the empirical calibration equation is given in Eq. (10). The correlation coefficient $R^{2}$ is 0.9019 , showing a good correlation between the regression results and the data points.

$$
w=\frac{-1.4637+\sqrt{K_{\mathrm{a}}}}{22.1373-1.4606 \sqrt{K_{\mathrm{a}}}} .
$$

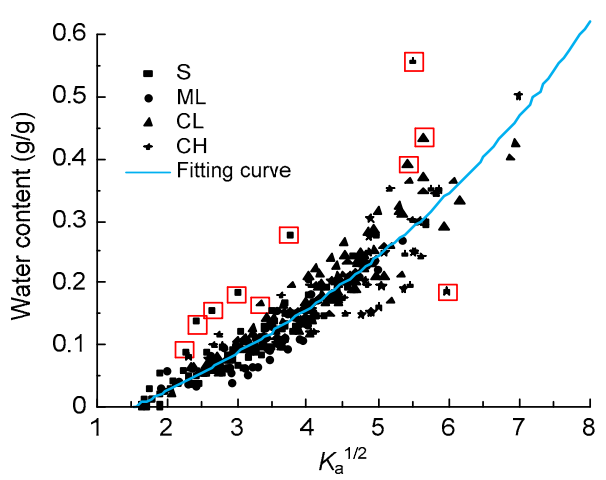

Fig. 2 Result of regression analysis by Eq. (10)

Eq. (10) ignores the influence of soil type, dry density, compaction energy, pore fluid conductivity, temperature, etc. To quantify and evaluate the effect of these elements on the accuracy of Eq. (10), statistical quantitative evaluation indexes are adopted as follows: (1) errors $(\Delta w)$ reflecting the difference between water contents calculated by Eq. (10) and by the oven dry method; (2) average errors $(E)$; (3) standard errors (SE); (4) standard errors of estimate (SEE). $E$ is used to evaluate the degree of deviation of the calculated result from the real value and SE indicates the discrete extent of $E$. SEE estimates the dispersion of the overall errors (Jung, 2011). The definitions of each parameter are shown as follows:

$$
\begin{gathered}
\Delta w=w-w_{\mathrm{o}}, \\
E=\frac{\sum_{1}^{N}|\Delta w|}{N}, \\
\mathrm{SE}=\sqrt{\frac{\sum_{1}^{N}(\Delta w-E)^{2}}{N}},
\end{gathered}
$$

$$
\mathrm{SEE}=\sqrt{\frac{\sum_{1}^{N}(\Delta w)^{2}}{N-2}},
$$

where $w_{0}$ is gravimetric water content obtained by the oven dry method and $N$ is the number of data points.

\subsection{Soil type effects}

Error variations along with water content for different soil types are shown in Fig. 3. Values of $E$, SE, SEE, and the distribution of errors are shown in Table 4.

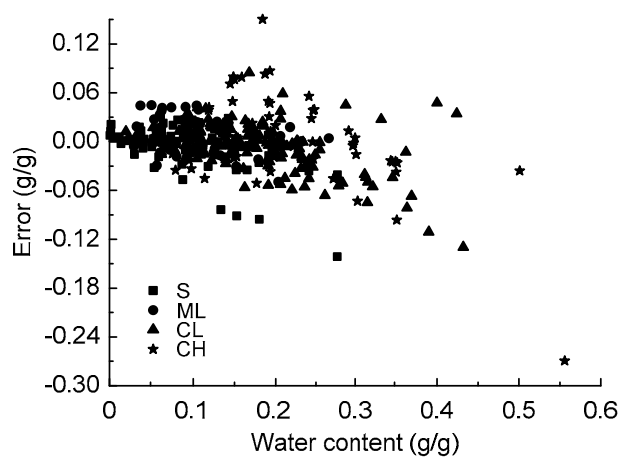

Fig. 3 Errors of water content by Eq. (10) vs. gravimetric water content for different soil types

As shown in Fig. 3, errors tend to increase with the increasing of water content. The reason is that the values of $A, B$, and $C$ are assumed constant in the proposed Eq. (9) and obtained through regression analysis, which means the variation of water content with dry density is ignored.

As shown in Table 4, the values of statistic parameters for $\mathrm{S}, \mathrm{ML}$, and $\mathrm{CL}$ soils are small and the ratio of errors within $\pm 0.03 \mathrm{~g} / \mathrm{g}$ are large, which indicates that Eq. (10) has a good accuracy for these soils. But for $\mathrm{CH}$ soils, it shows a relatively poor result, which can be attributed to ignorance of the effect of bound water for soils with high clay contents. In general, errors of most data points of all soil types are within $\pm 0.05 \mathrm{~g} / \mathrm{g}$.

\subsection{Dry density effects}

Errors varying with dry density are shown in Fig. 4. Values of $E, \mathrm{SE}, \mathrm{SEE}$, and the distribution of errors are shown in Table 5.

As shown in Fig. 4, errors show a relatively obvious dependency on the change of dry density. With 
the increasing of dry density, errors gradually vary from negative to positive, meaning that Eq. (10) underestimates the result in cases of low dry density and overestimates the result in cases of high dry density. Note that errors are large for low dry density soils. The reason can also be attributed to the neglect of variation of $A, B$, and $C$.

As shown in Table 5 , when dry density ranges around $1.3-2.3 \mathrm{~g} / \mathrm{cm}^{3}$, the statistic parameters $E$ and SEE are around $0.01-0.03 \mathrm{~g} / \mathrm{g}$ and errors within $\pm 0.05 \mathrm{~g} / \mathrm{g}$ are at a high level, indicating that Eq. (10) has a good accuracy for a wide scope of dry density

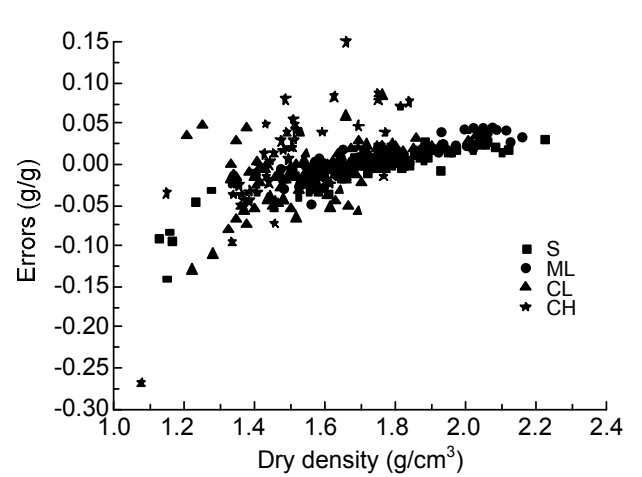

Fig. 4 Errors of water content by Eq. (10) vs. dry density cases. However, for dry density of $1.0-1.3 \mathrm{~g} / \mathrm{cm}^{3}$, it shows a poor result, which indicates that at this condition, the effect of dry density on the result of Eq. (10) cannot be ignored. Therefore, it is necessary to correct Eq. (10) to consider the effect of dry density.

In Eq. (9), parameters $A, B$, and $C$ are assumed to be constants. Actually, they are variables and have a relationship with dry density, etc. Herein, values of $A, B$, and $C$ are assumed to have a simple linear relation with dry density and then Eq. (9) becomes

$$
w=\frac{\left(a \frac{\rho_{\mathrm{d}}}{\rho_{\mathrm{w}}}+b\right)+\sqrt{K_{\mathrm{a}}}}{\left(c \frac{\rho_{\mathrm{d}}}{\rho_{\mathrm{w}}}+d\right)+\left(f \frac{\rho_{\mathrm{d}}}{\rho_{\mathrm{w}}}+g\right) \sqrt{K_{\mathrm{a}}}},
$$

where $a, b, c, d, f$, and $g$ are modified constants, $\rho_{\mathrm{d}}$ is the dry density, and $\rho_{\mathrm{w}}$ is the density of water.

The data points collected in this research are used to make regression analysis of the parameters in Eq. (15). The result empirical calibration equation is given in Eq. (16). The value of $R^{2}$ is 0.9413 .

Table 4 Errors for water content by Eq. (10) vs. different soil types

\begin{tabular}{|c|c|c|c|c|c|c|c|c|c|}
\hline \multirow{2}{*}{ Soil type } & \multirow{2}{*}{$\begin{array}{c}\text { Number of } \\
\text { data samples }\end{array}$} & \multirow{2}{*}{$E$} & \multirow{2}{*}{$\mathrm{SE}$} & \multirow{2}{*}{ SEE } & \multicolumn{5}{|c|}{ Distribution of error (\%) } \\
\hline & & & & & $\leq \pm 0.01 \mathrm{~g} / \mathrm{g}$ & $\leq \pm 0.02 \mathrm{~g} / \mathrm{g}$ & $\leq \pm 0.03 \mathrm{~g} / \mathrm{g}$ & $\leq \pm 0.04 \mathrm{~g} / \mathrm{g}$ & $\leq \pm 0.05 \mathrm{~g} / \mathrm{g}$ \\
\hline $\mathrm{S}$ & 74 & 0.019 & 0.023 & 0.031 & 40.5 & 66.2 & 83.8 & 91.9 & 94.6 \\
\hline ML & 68 & 0.017 & 0.013 & 0.022 & 39.7 & 67.7 & 83.8 & 89.7 & 100.0 \\
\hline $\mathrm{CL}$ & 148 & 0.022 & 0.022 & 0.031 & 34.5 & 62.2 & 75.7 & 81.8 & 89.2 \\
\hline $\mathrm{CH}$ & 62 & 0.036 & 0.041 & 0.056 & 22.6 & 37.1 & 56.5 & 71.0 & 80.7 \\
\hline
\end{tabular}

For distribution of error, the ' $\leq \pm 0.01$ ' column represents the percentage of errors within $\pm 0.01 \mathrm{~g} / \mathrm{g}$, the meanings of the rest columns are analogous, and the same below

Table 5 Errors for water content by Eq. (10) vs. different dry densities

\begin{tabular}{rccccccccc}
\hline $\begin{array}{c}\text { Density } \\
\left(\mathrm{g} / \mathrm{cm}^{3}\right)\end{array}$ & $\begin{array}{c}\text { Number of } \\
\text { data samples }\end{array}$ & $E$ & SE & SEE & \multicolumn{5}{c}{ Distribution of error (\%) } \\
\hline $1.0-1.3$ & 12 & 0.093 & 0.065 & 0.124 & 0.00 & 0.00 & 0.00 & 25.00 & 41.70 \\
$1.3-1.4$ & 25 & 0.036 & 0.024 & 0.045 & 4.00 & 28.00 & 52.00 & 64.00 & 76.00 \\
$1.4-1.5$ & 40 & 0.028 & 0.02 & 0.035 & 20.00 & 45.00 & 62.50 & 70.00 & 87.50 \\
$1.5-1.6$ & 72 & 0.018 & 0.015 & 0.024 & 37.50 & 63.90 & 79.20 & 90.30 & 95.80 \\
$1.6-1.7$ & 62 & 0.018 & 0.025 & 0.031 & 56.50 & 75.80 & 82.30 & 87.10 & 90.30 \\
$1.7-1.8$ & 63 & 0.013 & 0.018 & 0.022 & 57.10 & 81.00 & 93.70 & 95.20 & 95.20 \\
$1.8-1.9$ & 35 & 0.015 & 0.016 & 0.023 & 4.00 & 82.90 & 91.40 & 94.30 & 94.30 \\
$1.9-2.0$ & 14 & 0.021 & 0.009 & 0.025 & 7.14 & 57.10 & 85.70 & 92.90 & 100.00 \\
$2.1-2.3$ & 29 & 0.029 & 0.009 & 0.032 & 0.00 & 13.80 & 58.60 & 75.90 & 100.00 \\
\hline
\end{tabular}




$$
\begin{aligned}
& w= \\
& \frac{0.3039 \frac{\rho_{\mathrm{d}}}{\rho_{\mathrm{w}}}-2.1851+\sqrt{K_{\mathrm{a}}}}{\left(18.0283 \frac{\rho_{\mathrm{d}}}{\rho_{\mathrm{w}}}-17.9531\right)+\left(-0.6806 \frac{\rho_{\mathrm{d}}}{\rho_{\mathrm{w}}}+1.8351\right) \sqrt{K_{\mathrm{a}}}}
\end{aligned}
$$

Values of $E, \mathrm{SE}, \mathrm{SEE}$, and the distribution of errors after considering the effect of dry density by Eq. (16) are shown in Table 6.

Through Table 6, statistic parameters of soil samples with $1.0-1.3 \mathrm{~g} / \mathrm{cm}^{3}$ dry densities show obvious improvement. In reality, if information on dry density is available, Eq. (16) can offer a better accuracy.

Considering total density $\rho_{\mathrm{t}}$, which is more available in geotechnical engineering practice, Eq. (16) can be combined with the following equation:

$$
\rho_{\mathrm{d}}=\frac{\rho_{\mathrm{t}}}{1+w}
$$

Combining Eq. (16) and Eq. (17), we can obtain the following equation:

$$
w=\frac{-f_{2}+\sqrt{f_{2}^{2}-4 f_{1} f_{3}}}{2 f_{1}}
$$

where

$$
\begin{gathered}
f_{1}=-17.9531+1.8351 \sqrt{K_{\mathrm{a}}}, \\
f_{2}=18.0283 \rho_{\mathrm{t}}-0.6806 \rho_{\mathrm{t}} \sqrt{K_{\mathrm{a}}}+0.8351 \sqrt{K_{\mathrm{a}}}-15.768, \\
f_{3}=-0.3039 \rho_{\mathrm{t}}-\sqrt{K_{\mathrm{a}}}+2.1851 .
\end{gathered}
$$

Eq. (18) can offer the same accuracy as Eq. (16). As it is expressed in terms of total density, it can be more practical.

\subsection{Compaction energy effects}

For a unit soil with certain water content, when compacted with different compaction energy levels, the sample obtained will have different structures and compactness, which will influence the dielectric constant by the TDR test. For brevity, only comparisons of water content by Eq. (10) and the oven dry method for ASTM-CH soil are plotted in Fig. 5. Values of $E$, SE, SEE, and the distribution of errors for soil samples of ASTM Reference Soils and M1M5 soils with three compaction energy levels are shown in Table 7.

Fig. 5 and Table 7 show that, with the compaction energy increasing, $E$ and SEE have an increasing trend and the ratios of errors within $\pm 0.03 \mathrm{~g} / \mathrm{g}$ and $\pm 0.05 \mathrm{~g} / \mathrm{g}$ decrease correspondingly. This means

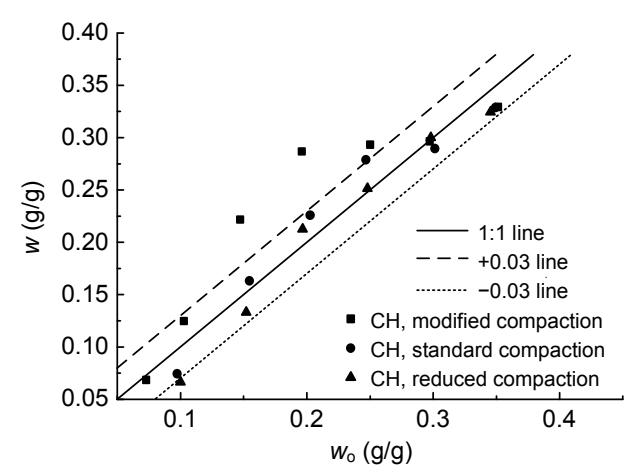

Fig. 5 Comparisons of water content by Eq. (10) and the oven dry method for ASTM-CH soil at different compaction energy levels

Table 6 Errors for water content by Eq. (16) vs. different dry densities

\begin{tabular}{cccccccccc}
\hline $\begin{array}{c}\text { Density } \\
\left(\mathrm{g} / \mathrm{cm}^{3}\right)\end{array}$ & $\begin{array}{c}\text { Number of } \\
\text { data samples }\end{array}$ & $E$ & SE & SEE & \multicolumn{5}{c}{ Distribution of error (\%) } \\
\cline { 6 - 9 } $1.0-1.3$ & 12 & 0.029 & 0.021 & 0.039 & 33.30 & 41.70 & 50.00 & 75.00 & 91.70 \\
$1.3-1.4$ & 25 & 0.020 & 0.018 & 0.028 & 48.00 & 52.00 & 68.00 & 88.00 & 92.00 \\
$1.4-1.5$ & 40 & 0.026 & 0.021 & 0.035 & 25.00 & 40.00 & 67.50 & 80.00 & 90.00 \\
$1.5-1.6$ & 72 & 0.016 & 0.014 & 0.021 & 48.60 & 75.00 & 83.30 & 93.10 & 97.20 \\
$1.6-1.7$ & 62 & 0.017 & 0.017 & 0.025 & 45.20 & 64.50 & 82.30 & 88.70 & 93.60 \\
$1.7-1.8$ & 63 & 0.009 & 0.008 & 0.012 & 66.70 & 90.50 & 96.80 & 100.00 & 100.00 \\
$1.8-1.9$ & 35 & 0.007 & 0.007 & 0.010 & 77.10 & 94.30 & 97.10 & 100.00 & 100.00 \\
$1.9-2.0$ & 14 & 0.008 & 0.004 & 0.010 & 71.40 & 100.00 & 100.00 & 100.00 & 100.00 \\
$2.1-2.3$ & 29 & 0.009 & 0.007 & 0.011 & 69.00 & 93.10 & 100.00 & 100.00 & 100.00 \\
\hline
\end{tabular}


that the errors of Eq. (10) increase with the increasing of compaction energy.

\subsection{Pore fluid conductivity effects}

Soils with different pore fluid conductivities will cause different energy losses under the TDR waveform, which will influence the value of their dielectric constants. Comparisons of water content by Eq. (10) and the oven dry method for ASTM-CH soil are shown in Fig. 6. Values of $E$, SE, SEE, and the distribution of errors for ASTM-CH soil with different pore fluid conductivity are shown in Table 8.

As shown in Fig. 6 and Table 8, with the pore fluid conductivity increasing, the statistical parameters $E$ and SEE have an increasing trend and the ratio of errors within $\pm 0.03 \mathrm{~g} / \mathrm{g}$ and $\pm 0.05 \mathrm{~g} / \mathrm{g}$ decrease

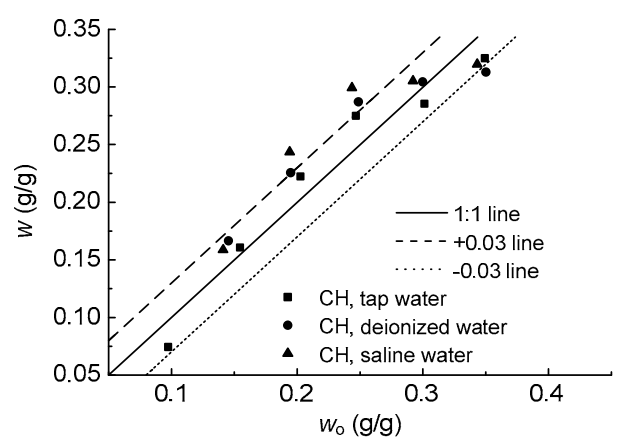

Fig. 6 Comparisons of water content by Eq. (10) and the oven dry method for ASTM-CH soil at different pore fluid conductivities correspondingly, which indicates that errors of Eq. (10) increase with the increasing of pore fluid conductivity. Note that the parameters for soil with deionized water as pore fluid seem not to be in accordance with the conclusion above, which may be because the constants in Eq. (10) are obtained mainly from soil samples with tap water as the pore fluid. In addition, as the samples are small and the salinity is at a low level, the conclusions above need to be further discussed.

\subsection{Temperature effects}

Temperature has a different effect on the value of dielectric constant for different soil types (Wraith and Or, 1999; Robinson et al., 2003; Schanz et al., 2011). Pepin et al. (1995) and Persson and Berndtsson (1998) found that for sandy soils, dielectric constant decreases with the increasing of temperature. Drnevich et al. (2001) pointed out that due to a large content of clay particles, the dielectric constant of cohesive soils increases with the increasing of temperature.

Drnevich et al. (2001) performed TDR tests on cohesive and cohesionless soils with temperatures ranging from $4{ }^{\circ} \mathrm{C}$ to $40{ }^{\circ} \mathrm{C}$. For brevity, only comparisons of water content by Eq. (10) and the oven dry method for Crosby Till soil are plotted in Fig. 7. Values of $E$, SE, SEE, and the distribution of errors for soil samples with different temperatures are shown in Table 9.

Table 7 Errors for water content by Eq. (10) at different compaction energy levels

\begin{tabular}{|c|c|c|c|c|c|c|c|c|c|}
\hline \multirow{2}{*}{$\begin{array}{c}\text { Compaction } \\
\text { method }\end{array}$} & \multirow{2}{*}{$\begin{array}{c}\text { Number of } \\
\text { data samples }\end{array}$} & \multirow{2}{*}{$E$} & \multirow{2}{*}{ SE } & \multirow{2}{*}{ SEE } & \multicolumn{5}{|c|}{ Distribution of error $(\%)$} \\
\hline & & & & & $\leq \pm 0.01 \mathrm{~g} / \mathrm{g}$ & $\leq \pm 0.02 \mathrm{~g} / \mathrm{g}$ & $\leq \pm 0.03 \mathrm{~g} / \mathrm{g}$ & $\leq \pm 0.04 \mathrm{~g} / \mathrm{g}$ & $\leq \pm 0.05 \mathrm{~g} / \mathrm{g}$ \\
\hline $\mathrm{MC}$ & 45 & 0.020 & 0.017 & 0.027 & 28.90 & 57.80 & 77.80 & 91.10 & 95.60 \\
\hline $\mathrm{SC}$ & 43 & 0.013 & 0.008 & 0.016 & 34.90 & 74.40 & 100.00 & 100.00 & 100.00 \\
\hline $\mathrm{RC}$ & 44 & 0.011 & 0.009 & 0.014 & 56.80 & 77.30 & 97.70 & 100.00 & 100.00 \\
\hline
\end{tabular}

Table 8 Errors for water content by Eq. (10) at different pore fluid conductivities

\begin{tabular}{cccccccccc}
\hline \multirow{2}{*}{$\begin{array}{c}\text { Pore } \\
\text { fluid }\end{array}$} & $\begin{array}{c}\text { Number of } \\
\text { data samples }\end{array}$ & \multirow{2}{*}{$E$} & SE & SEE & \multicolumn{5}{c}{ Distribution of error (\%) } \\
\cline { 6 - 9 } & & & & & $\leq \pm 0.01 \mathrm{~g} / \mathrm{g}$ & $\leq \pm 0.02 \mathrm{~g} / \mathrm{g}$ & $\leq \pm 0.03 \mathrm{~g} / \mathrm{g}$ & $\leq \pm 0.04 \mathrm{~g} / \mathrm{g}$ & $\leq \pm 0.05 \mathrm{~g} / \mathrm{g}$ \\
\hline DI & 5 & 0.026 & 0.013 & 0.038 & 20.00 & 20.00 & 40.00 & 100.00 & 100.00 \\
TAP & 6 & 0.020 & 0.007 & 0.026 & 16.70 & 50.00 & 100.00 & 100.00 & 100.00 \\
SAL & 5 & 0.032 & 0.017 & 0.047 & 0.00 & 40.00 & 60.00 & 60.00 & 80.00 \\
\hline
\end{tabular}

DI: deionized water; TAP: tap water; SAL: saline water (about twice pore fluid conductivity of TAP). For distribution of error, the ' $\leq \pm 0.01$ ' column represents the percentage of errors within $\pm 0.01 \mathrm{~g} / \mathrm{g}$, and the meanings of the rest columns are analogous 
As shown in Fig. 7 and Table 9, the statistical parameters $E$ and SEE are relatively large, which is mainly due to the presence of some scattered data, specifically, the data points above $0.4 \mathrm{~g} / \mathrm{g}$ with a low dry density. Errors trend to decrease with the increasing in temperature. When the temperature is within $4-30{ }^{\circ} \mathrm{C}$, it has no significant influence on the result of Eq. (10). Drnevich et al. (2001) pointed out that the effect of temperatures from $5{ }^{\circ} \mathrm{C}$ to $20^{\circ} \mathrm{C}$ can be ignored since their influence is small. ASTM (2012a) presents the equations used to modify the effect of temperature.

\subsection{Comparison of Topp's equation and 'two- step method' equation}

Topp et al. (1980) proposed a widely used empirical calibration equation:

$$
\begin{aligned}
\theta= & 4.3 \times 10^{-6} K_{\mathrm{a}}^{3}-5.5 \times 10^{-4} K_{\mathrm{a}}^{2} \\
& +2.92 \times 10^{-2} K_{\mathrm{a}}-5.3 \times 10^{-2},
\end{aligned}
$$

where $\theta$ is the volumetric water content.

Gravimetric water content $(w)$ and volumetric water content $(\theta)$ are related as follows:

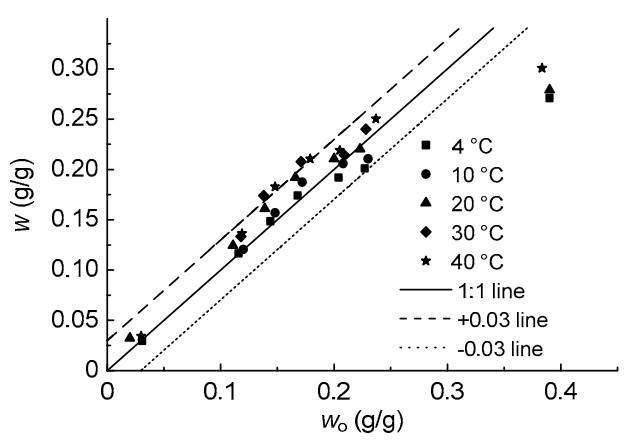

Fig. 7 Comparisons of water content by Eq. (10) and the oven dry method for Crosby Till soil at different temperatures

$$
w=\frac{\rho_{\mathrm{w}}}{\rho_{\mathrm{d}}} \theta .
$$

Combining Eqs. (19) and (20), the gravimetric water content calculated by Topp's equation is obtained.

Siddiqui and Drnevich (1995) performed the 'two-step method' to test the water content and dry density of soil. The empirical calibration equation they developed is

$$
\sqrt{K_{\mathrm{a}}} \frac{\rho_{\mathrm{w}}}{\rho_{\mathrm{d}}}=a_{1}+b_{1} w
$$

where $a_{1}$ and $b_{1}$ are calibration constants.

Drnevich et al. (2005) pointed out that although calibration constants in Eq. (21) are soil-dependent, uniform calibration constants can be used within acceptable limits for engineering practice. Herein, the values of $a_{1}$ and $b_{1}$ are 1 and 8.5 for cohesionless soils and 0.95 and 8.8 for cohesive soils, respectively, as recommended by Drnevich et al. (2005).

Comparisons of water content calculated by Eq. (10), Topp's equation, Eq. (21), and Eq. (16) are shown in Table 10.

As shown in Table 10, results calculated by Topp's equation, Eq. (21), and Eq. (10) are very close. Compared with Topp's equation which expresses water content in volumetric form and the 'two-step method' equation which considers the influence of dry density, the statistical parameters $E$ and SEE of Eq. (10) are slightly larger than those in the two other methods. After being modified by considering the dry density effects, Eq. (16) has a better accuracy.

Through the analysis above, Eq. (10) shows a good accuracy for most of soil types and a slight

\begin{tabular}{|c|c|c|c|c|c|c|c|c|c|}
\hline \multirow{2}{*}{$\begin{array}{c}\text { Temperature } \\
\left({ }^{\circ} \mathrm{C}\right)\end{array}$} & \multirow{2}{*}{$\begin{array}{c}\text { Number of } \\
\text { data samples }\end{array}$} & \multirow{2}{*}{ E } & \multirow{2}{*}{$\mathrm{SE}$} & \multirow{2}{*}{ SEE } & \multicolumn{5}{|c|}{ Distribution of error (\%) } \\
\hline & & & & & $\leq \pm 0.01 \mathrm{~g} / \mathrm{g}$ & $\leq \pm 0.02 \mathrm{~g} / \mathrm{g}$ & $\leq \pm 0.03 \mathrm{~g} / \mathrm{g}$ & $\leq \pm 0.04 \mathrm{~g} / \mathrm{g}$ & $\leq \pm 0.05 \mathrm{~g} / \mathrm{g}$ \\
\hline 4 & 23 & 0.056 & 0.066 & 0.090 & 21.70 & 34.80 & 47.80 & 56.50 & 65.20 \\
\hline 10 & 11 & 0.053 & 0.080 & 0.106 & 27.30 & 54.60 & 72.70 & 72.70 & 72.70 \\
\hline 20 & 22 & 0.048 & 0.061 & 0.081 & 22.70 & 40.90 & 63.60 & 68.20 & 68.20 \\
\hline 30 & 15 & 0.049 & 0.065 & 0.087 & 26.70 & 53.30 & 53.30 & 66.70 & 66.70 \\
\hline 40 & 17 & 0.034 & 0.047 & 0.062 & 23.50 & 58.80 & 70.60 & 82.40 & 82.40 \\
\hline
\end{tabular}
influence by a wide range of dry densities, compaction energy levels, and pore fluid conductivity, at

Table 9 Errors for water content by Eq. (10) at different temperatures 
Table 10 Comparison of water content obtained by Eq. (10), Topp's equation, Eq. (21), and Eq. (16)

\begin{tabular}{cccccccccc}
\hline Equation & $\begin{array}{c}\text { Number of } \\
\text { data samples }\end{array}$ & $E$ & SE & SEE & \multicolumn{5}{c}{ Distribution of error (\%) } \\
\cline { 7 - 10 } & 352 & 0.023 & 0.026 & 0.035 & 34.70 & 59.70 & 75.60 & 83.50 & 90.90 \\
Eq. (10) & 352 & 0.020 & 0.018 & 0.027 & 29.60 & 65.30 & 81.50 & 89.20 & 93.20 \\
Topp's equation & $350.01 \mathrm{~g} / \mathrm{g}$ & $\leq \pm 0.02 \mathrm{~g} / \mathrm{g} \leq \pm 0.03 \mathrm{~g} / \mathrm{g} \leq \pm 0.04 \mathrm{~g} / \mathrm{g} \leq \pm 0.05 \mathrm{~g} / \mathrm{g}$ \\
$\begin{array}{c}\text { (Topp et al., 1980) } \\
\text { Eq. (21) }\end{array}$ & 352 & 0.018 & 0.021 & 0.028 & 45.50 & 75.60 & 82.70 & 88.10 & 92.30 \\
Eq. (16) & 352 & 0.015 & 0.016 & 0.022 & 53.40 & 73.60 & 84.90 & 92.60 & 96.30 \\
\hline
\end{tabular}

temperatures commonly encountered in engineering practice.

\section{Conclusions}

From the database including 45 kinds of soil samples and 418 data points, an empirical calibration equation has been developed to relate gravimetric water content directly with apparent dielectric constant. The main conclusions are as follows:

1. The accuracy of the new empirical calibration equation is within $\pm 0.05 \mathrm{~g} / \mathrm{g}$ for commonly encountered soils.

2. The new empirical calibration equation underestimates the result in low dry density and overestimates the result in high dry density. For dry density ranging between 1.3 and $2.3 \mathrm{~g} / \mathrm{cm}^{3}$, the new empirical calibration equation shows a good accuracy.

3 . Errors of the new empirical calibration equation tend to increase with the increasing of compaction energy and pore fluid conductivity. However, for the commonly encountered ranges of compaction energy and pore fluid conductivity, the new empirical calibration has a good accuracy.

4. Temperature has no sensible influence on the results from the new empirical calibration equation when it is used within $4-30^{\circ} \mathrm{C}$.

5. This empirical calibration equation can be used to measure water content by the TDR method conveniently and efficiently in engineering practice without calibration.

\section{References}

Abu-Hassanein, Z.S., Benson, C.H., Blotz, L.R., 1996. Electrical resistivity of compacted clays. Journal of $\mathrm{Ge}$ otechnical Engineering, 122(5):397-406.

http://dx.doi.org/10.1061/(ASCE)0733-9410(1996)122:5 (397)
ASTM, 2007. Standard Test Methods for Laboratory Compaction Characteristics of Soil Using Standard Effort, D698-07. American Society for Testing and Materials, West Conshohocken, USA.

ASTM, 2009. Standard Test Methods for Laboratory Compaction Characteristics of Soil Using Modified Effort, D1557-09. American Society for Testing and Materials, West Conshohocken, USA.

ASTM, 2010. Standard Practice for Classification of Soils for Engineering Purposes, D2487-10. American Society for Testing and Materials, West Conshohocken, USA.

ASTM, 2012a. Standard Test Method for Water Content and Density of Soil in situ by Time Domain Reflectometry (TDR), D6780-12. American Society for Testing and Materials, West Conshohocken, USA.

ASTM, 2012b. Standard Test Methods for Laboratory Compaction Characteristics of Soil Using Standard Effort, D698-12. American Society for Testing and Materials, West Conshohocken, USA.

Baker, J.M., Allmaras, R.R., 1990. System for automating and multiplexing soil moisture measurement by timedomain reflectometry. Soil Science Society of America Journal, 54(1):1-6. http://dx.doi.org/10.2136/sssaj1990.03615995005400010 $001 \mathrm{x}$

Birchak, J.R., Gardner, C.G., Hipp, J.E., et al., 1974. High dielectric constant microwave probes for sensing soil moisture. Proceedings of the IEEE, 62(1):93-98. http://dx.doi.org/10.1109/PROC.1974.9388

Chen, W., 2011. The Design of TDR Probe and Monitoring Technology of Water Content and Dry Density. MS Thesis, Zhejiang University, Hangzhou, China (in Chinese).

Chen, Y., 2011. Study on Dielectric Constant and Water Content Measurement of Highly Conductive Geomaterials by TDR Technique. PhD Thesis, Zhejiang University, Hangzhou, China (in Chinese).

Chen, Y.M., 2014. A fundamental theory of environmental geotechnics and its application. Chinese Journal of $\mathrm{Ge}$ otechnical Engineering, 36(1):1-46 (in Chinese). http://dx.doi.org/10.11779/CJGE201401001

Chen, Y.M., Bian, X.C., Chen, R.P., et al., 2003. Propagation of electromagnetic wave in the three phases soil media. Applied Mathematics and Mechanics, 24(6):691-699. http://dx.doi.org/10.1007/BF02437870 
Chen, Y.M., Wang, H.L., Chen, R.P., et al., 2014. A newly designed TDR probe for soils with high electrical conductivities. Geotechnical Testing Journal, 37(1):36-45. http://dx.doi.org/10.1520/GTJ20120227

Cui, Y.J., Duong, T.V., Tang, A.M., et al., 2013. Investigation of the hydro-mechanical behaviour of fouled ballast. Journal of Zhejiang University-SCIENCE A (Applied Physics \& Engineering), 14(4):244-255. http://dx.doi.org/10.1631/jzus.A1200337

Dirksen, C., Dasberg, S., 1993. Improved calibration of time domain reflectometry soil water content measurements. Soil Science Society of America Journal, 57(3):660-667. http://dx.doi.org/10.2136/sssaj1993.03615995005700030 $005 \mathrm{x}$

Dobson, M.C., Ulaby, F.T., Hallikainen, M.T., et al., 1985. Microwave dielectric behavior of wet soil-Part II: dielectric mixing models. IEEE Transactions on Geoscience and Remote Sensing, GE-23(1):35-46. http://dx.doi.org/10.1109/TGRS.1985.289498

Drnevich, V.P., Lin, C.P., Yi, Q., et al., 2001. Real-time Determination of Soil Type, Water Content, and Density Using Electromagnetics. Technical Report No. FHWA/ IN/JTRP-2000/20, Purdue University, West Lafayette, USA.

Drnevich, V.P., Ashmawy, A.K., Yu, X., et al., 2005. Time domain reflectometry for water content and density of soils: study of soil-dependent calibration constants. $\mathrm{Ca}$ nadian Geotechnical Journal, 42(4):1053-1065. http://dx.doi.org/10.1139/T05-047

Feng, W., Lin, C.P., Drnevich, V.P., et al., 1998. Automation and standardization of measuring moisture content and density using time domain reflectometry. Technical Report No. FHWA/IN/JTRP-98/4, Purdue University, USA.

Heimovaara, T.J., Bouten, W., Verstraten, J.M., 1994. Frequency domain analysis of time domain reflectometry waveforms: 2. A four-component complex dielectric mixing model for soils. Water Resources Research, 30(2):201-209. http://dx.doi.org/10.1029/93WR02949

Herkelrath, W.N., Hamburg, S.P., Murphy, F., 1991. Automatic, real-time monitoring of soil moisture in a remote field area with time domain reflectometry. Water Resources Research, 27(5):857-864. http://dx.doi.org/10.1029/91WR00311

Hook, W.R., Livingston, N.J., 1996. Errors in converting time domain reflectometry measurements of propagation velocity to estimates of soil water content. Soil Science Society of America Journal, 60(1):35-41. http://dx.doi.org/10.2136/sssaj1996.03615995006000010 $008 \mathrm{x}$

Imhoff, P.T., Reinhart, D.R., Englund, M., et al., 2007. Review of state of the art methods for measuring water in landfills. Waste Management, 27(6):729-745. http://dx.doi.org/10.1016/j.wasman.2006.03.024
Jacobsen, O.H., Schjønning, P., 1993. A laboratory calibration of time domain reflectometry for soil water measurement including effects of bulk density and texture. Journal of Hydrology, 151(2-4):147-157. http://dx.doi.org/10.1016/0022-1694(93)90233-Y

Jung, S., 2011. New Methodology for Soil Characterization Using Time Domain Reflectometry (TDR). PhD Thesis, Purdue University, West Lafayette, USA.

Ledieu, J., de Ridder, P., de Clerck, P., et al., 1986. A method of measuring soil moisture by time-domain reflectometry. Journal of Hydrology, 88(3-4):319-328. http://dx.doi.org/10.1016/0022-1694(86)90097-1

Lin, C.P., 1999. Time Domain Reflectometry for Soil Properties. PhD Thesis, Purdue University, West Lafayette, USA.

Malicki, M.A., Plagge, R., Roth, C.H., 1996. Improving the calibration of dielectric TDR soil moisture determination taking into account the solid soil. European Journal of Soil Science, 47(3):357-366. http://dx.doi.org/10.1111/j.1365-2389.1996.tb01409.x

Masbruch, K., Ferré, T.P.A., 2003. A time domain transmission method for determining the dependence of the dielectric permittivity on volumetric water content. Vadose Zone Journal, 2(2):186-192. http://dx.doi.org/10.2136/vzj2003.1860

Noborio, K., 2001. Measurement of soil water content and electrical conductivity by time domain reflectometry: a review. Computers and Electronics in Agriculture, 31(3):213-237. http://dx.doi.org/10.1016/S0168-1699(00)00184-8

Pepin, S., Livingston, N.J., Hook, W.R., 1995. Temperaturedependent measurement errors in time domain reflectometry determinations of soil water. Soil Science Society of America Journal, 59(1):38-43.

http://dx.doi.org/10.2136/sssaj1995.03615995005900010 006x

Persson, M., Berndtsson, R., 1998. Texture and electrical conductivity effects on temperature dependency in time domain reflectometry. Soil Science Society of America Journal, 62(4):887-893.

http://dx.doi.org/10.2136/sssaj1998.03615995006200040 006x

Ponizovsky, A.A., Chudinova, S.M., Pachepsky, Y.A., 1999. Performance of TDR calibration models as affected by soil texture. Journal of Hydrology, 218(1-2):35-43. http://dx.doi.org/10.1016/S0022-1694(99)00017-7

Rathje, E.M., Wright, S.G., Stokoe II, K.H., et al., 2006. Evaluation of non-nuclear methods for compaction control. Technical Report No. FHWA/TX-06/0-4835-1, Center for Transportation Research, University of Texas at Austin, USA.

Robinson, D.A., Jones, S.B., Wraith, J.M., et al., 2003. A review of advances in dielectric and electrical conductivity measurement in soils using time domain reflectometry. Vadose Zone Journal, 2(4):444-475. http://dx.doi.org/10.2136/vzj2003.4440 
Schanz, T., Baille, W., Tuan, L.N., 2011. Effects of temperature on measurements of soil water content with time domain reflectometry. Geotechnical Testing Journal, 34(1): $1-8$. http://dx.doi.org/10.1520/GTJ103152

Siddiqui, S.I., Drnevich, V.P., 1995. A new method of measuring density and moisture content of soil using the technique of time domain reflectometry. Technical Report No. FHWA/IN/JHRP-95/09, Purdue University, USA.

Topp, G.C., Davis, J.L., Annan, A.P., 1980. Electromagnetic determination of soil water content: measurements in coaxial transmission lines. Water Resources Research, 16(3):574-582. http://dx.doi.org/10.1029/WR016i003p00574

Wraith, J.M., Or, D., 1999. Temperature effects on soil bulk dielectric permittivity measured by time domain reflectometry: experimental evidence and hypothesis development. Water Resources Research, 35(2):361-369. http://dx.doi.org/10.1029/1998WR900006

$\mathrm{Xu}, \mathrm{W} ., 2008$. Theory and Technology for Measurement of Soil Water Content by Time Domain Reflectometry Surface Reflections. MS Thesis, Zhejiang University, Hangzhou, China (in Chinese).

Yu, C., Warrick, A.W., Conklin, M.H., et al., 1997. Two- and three-parameter calibrations of time domain reflectometry for soil moisture measurement. Water Resources Research, 33(10):2417-2421. http://dx.doi.org/10.1029/97WR01699

Yu, X., Drnevich, V.P., 2004. Soil water content and dry density by time domain reflectometry. Journal of Geotechnical and Geoenvironmental Engineering, 130(9): 922-934.

http://dx.doi.org/10.1061/(ASCE)1090-0241(2004)130:9 (922)

Zambrano, C.E., 2006. Soil Type Identification Using Time Domain Reflectometry. MS Thesis, Purdue University, West Lafayette, USA.

\section{中文概要}

题 目: 土体含水率时域反射法现场测试经验模型研究

目的：建立含水率与介电常数间的经验关系模型是利 用时域反射（TDR）技术测试土体含水率的关 键。通过收集并建立包含 45 种土样 418 个试验 数据点的数据库, 提出一个土体质量含水率与 表观介电常数间的经验公式, 分析经验公式误 差随土体类型、干密度、击实功、孔隙水电导 率和温度等因素的变化规律, 并提出考虑干密 度影响的修正方法。

创新点: 1. 基于电磁波相互作用理论, 直接建立土体质 量含水率和介电常数间的关系模型; 2. 通过数 据拟合得到通用型经验公式, 可在现场无标定 快速高效地实现含水率测试。

方 法: 1. 通过理论分析, 直接建立土体质量含水率和 介电常数间的关系模型（公式（9））；2. 通过 试验数据收集和回归分析得到通用型经验公式 （图 2 和公式（10））；3. 通过影响因素分 析, 对公式的适用性和有效性进行分析 (图 3 7）。

结 论: 1. 该经验公式对常见的土体类型均能给出误差 在 $\pm 0.05 \mathrm{~g} / \mathrm{g}$ 以内的结果; 2. 在 $1.3 \sim 2.3 \mathrm{~g} / \mathrm{cm}^{3}$ 的 干密度范围内, 该经验公式具有较好的适用 性; 在工程中常见的击实功和孔隙水电导率变 化范围内, 含水率测试精度可满足工程要求; $4 \sim 30{ }^{\circ} \mathrm{C}$ 温度变化范围对本经验公式的计算结果 无明显影响; 3. 利用该经验公式, 对于特殊场 地, 可以不通过标定实现 TDR 现场测试, 具有 较好的实用性。

关键词: 土体; 质量含水率; 时域反射法; 经验公式 